\title{
Ontluikende denke in die GKSA-kerkgroeibediening
}

\author{
Author: \\ Sophia (Phia) van Helden ${ }^{1}$ \\ Affiliation: \\ ${ }^{1}$ Faculty of Theology, \\ North-West University, \\ Potchefstroom Campus, \\ South Africa \\ Correspondence to: \\ Sophia van Helden \\ Email: \\ Sophiavhelden@gmail.com \\ Postal address: \\ PO Box 16197, Lyttelton \\ 0140, South Africa \\ Dates: \\ Received: 22 Apr. 2015 \\ Accepted: 03 July 2015 \\ Published: 25 Sept. 2015 \\ How to cite this article: \\ Van Helden, S., 2015, \\ 'Ontluikende denke in die \\ GKSA-kerkgroeibediening', \\ In die Skriflig 49(1), Art. \\ \#1978, 12 pages. http:// \\ dx.doi.org/10.4102/ids. \\ v49i1.1978

\section{Copyright:} \\ C 2015. The Authors. \\ Licensee: AOSIS \\ OpenJournals. This work is \\ licensed under the Creative \\ Commons Attribution \\ License.
}

Read online:

Scan this QR

code with your

smart phone or

mobile device

to read online.
Die GKSA het in 2012 besluit om heelhartig en volkome na God se bevele terug te keer. Herbesinning oor wat God in sy Woord beveel, is deel van die denkveranderingsproses wat in die GKSA plaasvind. Daar is baie oorsake vir die komplekse tendens van krimpende gereformeerde lidmaatgetalle waaraan die mens nie werklik iets kan doen nie. Die enigste optrede van gelowiges onder die leiding van die Heilige Gees wat moontlik 'n verskil kan maak, is om deur diepgaande bekering hulle eie denke volledig en gehoorsaam volgens die Skrif aan te pas. Omdat ingrypende veranderinge met verloop van tyd plaasvind, is dit nodig om die proses diachronies en aan die hand van verskillende metodologieë te volg. Hierdie artikel poog om 'n bydrae tot die proses te lewer.

Emerging thinking in the RCSA churchgrowth ministry. In 2012 the RCSA decided towards a wholehearted and total turnaround regarding God's commands. Reassessing of what God commands in his Word is part of the process of thought change taking place in the RCSA. There are many causes for the complex trend of declining numbers in reformed churches towards which man cannot do anything. The only action believers can undertake under the guidance of the Holy Spirit is to obediently adapt their own thinking completely according to the Word by profound repentance. Because of far-reaching change occurring over time, it is necessary to follow the process diachronically as well as by means of different methodologies. This article seeks to contribute toward this process

\section{Inleiding}

'Gereformeerdes was altyd gereed om in nuwe situasies met nuwe uitdagings ook nuut na die Woord te gaan kyk, en om hulle verstaan van die belydenis en die praktyke en bedienings van die kerk in die lig daarvan te heroorweeg'. Die aanhaling van Coenie Burger (Niemandt 2007:48) belig die een kant van die verskuiwingsproses (Niemandt 2013a:11-191). Die ander kant is dat gelowiges in die veranderende tye steeds 'vasklou' aan die 'vertroude denkskema van die Modernisme' (Niemandt 2007:42) wat 'n laertrek-praksis van kerkwees daargestel het (Niemandt 2007:36, 37). Heroorwegende denke beweeg weg van die laertrek-gesindheid af en toon mettertyd nuwe insigte of denke oor die sturende God (missio Dei) se werk (Niemandt 2013b:37-42, 25).

Drie jaar na die 2012-GKSA-sinodebesluit en die werk van die Deputate Omkeerstrategie ${ }^{1}$ (Venter 2012a; 2012b; 2012c; 2014), is dit noodsaaklik om die verstaan en die stand van denke binne die GKSA weer van nader te beskou. Voor die eeuwenteling, en selfs tot en met 2012, het die GKSA stelselmatig bewus geword daarvan dat die Groot Opdrag in die praksis van kerkwees onvolledig verstaan en uitgeleef word en dat 'n missionale aanpak van bediening in die praksis van kerkwees sowel as tydens die opleiding van leraars, nie prioriteit gekry nie (Buys 2013; vgl. Rheeder 2013; Van Helden 2013b:8, 9). Die ongesonde praksis het deur die krimpende tendens krisisafmetings begin aanneem en om diepgaande omkeer geroep ter wille van missionale kerkgroei (Niemandt 2007:1, 12; Van Helden 2013b:8, 9).

God se doel met sy kerk (missio Dei) word deur ontluikende missionale denke binne gemeentes herken; 'n doel waardeur elke gelowige - leiers sowel as volgelinge - geroep en gestuur word (Niemandt 2013b:147, 167-173; Rheeder 2008:157). 'n Missionale bediening dui daarop dat God sy kinders deel van sy sending (missio Dei) maak (Niemandt 2013b:34-40). Herbesinning hieroor vind tans binne die praksis van krimpende gereformeerde kerkverbande plaas.

Hierdie krisiskonteks (Van Helden 2013a:1-12; 2014b:2) het duideliker geword deur die drasties krimpende lidmaatgetalle - ook binne die GKSA (Kleynhans 2013; Niemandt 2013a; Van Helden 
2013a:1-16). Die krisistendens wat ook wêreldwyd binne die tradisionele hoofstroomkerke waargeneem word (Hendriks 1999:18, 2000:79, 95), sorteer binne die navorsingsterrein van Praktiese Teologie as krisiswetenskap (Heitink, Pieterse \& Vos 2000:54). Navorsing oor moontlike denkverandering binne 'n krisistendens, behoort beweging te toon wat deur kommunikatiewe handelinge plaasvind vanaf krisispraksis 1 na 'n verbeterende praksis 2 .

'Missionale leierskap is 'n verskuiwing in denke', aldus Niemandt (2013b:151). Dit dui op 'n kloof tussen tradisionele denke (vgl. 'laertrek'-denke) en missionale denke. Die kloof is só groot dat diepgaande bekering of omkeer behoort plaas te vind om dit te oorbrug (Rheeder 2012). Nuwe roetes behoort gevind te word. Dit doen God deur sy Gees, maar dit ontneem die gelowige nie sy verantwoordelikheid om aktief deel te wees in die soeke na nuwe denke binne die veranderende konteks nie (vgl. Heitink et al. 2000:54).

Wanneer die tendens nagegaan word, is dit noodsaaklik om op Skrifbeginsels te fokus. Om insae te verkry oor Skrifbeginsels rakende groeimoontlikhede binne gemeentes, het Schwarz (vgl. 1999; 2000), onder andere, hieroor wêreldwyd navorsing gedoen. Die basis van hierdie navorsing is die Groot Opdrag (Matt 28:16-20) en hoe dit missionaal deur opbou en uitbou as eenheidsisteem 'n vernuwende Christosentriese denkwyse en veranderde praksis in kerkwees daar kan stel. Daar behoort dus 'n verskuiwing wég van die institusionalistiese denkpatroon plaas te vind (I-denke) wat sprekend is van 'n ongesonde praksis van kerkwees (Van Helden 2013a:1-12).

Indien só 'n verskuiwing plaasvind, behoort dit mettertyd waarneembaar te wees as 'n ontluikende ${ }^{3}$ praksis waar missionaalgerigte denke manifesteer. Hierdie artikel bied navorsing in verband met die ontluikende verskuiwende denke binne die GKSA. Omdat denkverskuiwing 'n proses is, is die navorsing deel van diachroniese ${ }^{4}$ data; data wat tendense, beweging of vloeibaarheid, innovasie, verskuiwings en waagmoed as gevolg van veranderende denke aandui (vgl. Niemandt 2007:12, 51, 52).

2.Missionale leierskap toon 'n denkverskuiwing: van ' $n$ leier as bemiddelaar van God na ' $n$ leier as fasiliteerder van bedienings; van gesentraliseerde kontrole na . 'nentraliseerde verhoudings; van die skepper van werksopdrate na die na gedesentraliseerde verhoudings; van die skepper van werksopdragte na die die hoofuitvoerende beampte na die geestelike begeleier; van mobiliseerder na deelnemer (Niemandt 2013b:151).

3.Nuwe soort/ontluikende leierskap teenoor ou leierskap behels die volgende: missionale leierskap wat gebou is op bemagtiging, deelname en spanne teenoo modernistiese leierskap gebou op kontrole, beheer en hiërargie; kreatiewe vryheid teenoor streng kontrole; almal se visie deur ' $n$ proses van deelname teenoor die leier se visie wat alles bepaal; leierlose groepe en spanwerk teenoor kragdadige leiers; leierskap deur diegene wat gawes ontvang het teenoor leierskap deu diegene wat gewillig is om die werk te doen; invloed vloei uit passie en deelname teenoor gesag wat uit die posisie wat die leier in die hiërargie het vloei; oop sisteem wat maklike nuwe toetredes verwelkom teenoor 'n geslote sisteem waar die leiers saam 'n klub vorm; die gemeente bepaal die leiers se agenda teenoor die leier wat die gemeente se agenda bepaal- sterk klem op uitbou van konsensus teenoor die sterk klem op besluitneming (Niemandt 2007:157)

4.'n Diachroniese studie dui op navorsing wat met verloop van tyd plaasvind en wat tydvakke volg wat met mekaar vergelyk kan word (Odendal \& Gouws 2010:160). 'n Sinchroniese studie dui op ' $n$ onderwerp wat in tyd op ' $n$ enkele tydstip bestudeer word (Odendal \& Gouws 2010:1001). Hierdie artikel vertoon drie sinchroniese studies, naamlik die van 2009, 2012 en 2015. Deur die bewegende tendense in elk studie te volg en te vergelyk, word die spesifieke onderwerp diachroniese benader
Drie studies met die oog op diachroniese data is afgehandel: Eerstens, 2009: denke van GKSA-gemeentelede aan die hand van 'n steekproef binne twee provinsies. Tweedens, 2012-GKSA-Sinode: die denkstand van GKSA-afgevaardigdes aan die hand van 'n vraelys. Derdens, 2014/2015: denke van GKSA-leraars waarvan die inligting empiries verkry is deur kerklike statistiek, 'n vraelys en gesprekke. Deur die statistiek is vasgestel aan watter gemeentes die vraelys gestuur moet word, sodat die inligting wat verkry is oor daardie spesifieke gemeente, statisties verwerk kan word. Die vraelys het'n aantal kernaspekte binne die kerkgroeibediening nagevors. Die referente was GKSA-leraars en die doel was om 'n moontlike ontluiking van missionale denke en dade na te speur. Gesprekke is gevoer met leraars waar groei volgens statistiek aangetoon is. Die gemengde kwantitatief-kwalitatiewe metode sluit aan by die histories-interpretatiewe navorsing (Heitink et al. 2000:54) (Praksis 1 verskuif verbeterend na Praksis 2; vgl. Addendum 1).

\section{Kerklike statistiek}

Kerklike statistiek word gereeld gebruik om kerklike inligting te bekom. Die aanvaarde uitgangspunt oor kerklike statistiek is egter dat een uit elke twee respondente die volle waarheid weergee. Die rede is dat respondente terugvoer gee soos wat hulle dink die antwoord behoort te wees (sosiale wenslikheidsvooroordeel) (Dreyer 2009:1, 2, 14; Gill 2003: 18-20). Wêreldwyd bevestig ook sosioloë die uitgangspunt dat kerklike statistiek as oordrewe aangebied word (Gill 2003:11-21; Hadaway \& Marler 2005:217-232; Iannaccone 2004:191-207; Smietana 2006:85-88; Ward 2004:2-12; Wilhelm, Roony \& Temple 2007:1).

Wanneer jaarboeke en almanakke as bronne van gereformeerde kerkverbande gebruik word, word leemtes in die samestelling van aangevraagde inligting, waargeneem (Pansegrouw 2015). Belangrike inligting ontbreek in GKSA-Almanakke, ${ }^{5}$ byvoorbeeld by die beëindiging van lidmaatskap (vgl. Vogel 2008, 2014). Vir 'n kerkverband wat in 'n nypende krisis verkeer (vgl. Bosch 1991:2, 3, 7; Van Helden 2013a), behoort meer besonderhede vir kerkverlating ingewin te word (Pansegrouw 2015), sodat die oorsaak van die probleem geïdentifiseer en aanbevelings ter verbetering daarvan gemaak kan word. Ten spyte van moontlike tekortkominge, word die beskikbare statistiek as navorsingsbron gebruik sodat moontlike tendense aangetoon kan word.

In die lig van moontlike tekorte is die mees betroubare gegewens data wat binne dieselfde geografiese area oor ten minste twee punte oor 'n tydperk (diachronies) nagevors word (Gill 2003:18-20). Met hierdie artikel word die tendense aangetoon in die veranderende GKSA-praksis van kerkwees (eerste punt van ooreenstemming) as gevolg van veranderende denke

5.In GKSA-Almanakke word die statistiek jaarliks deur die Administratiewe Buro in Potchefstroom van elke gemeente aangevra rakende getalle van belydende lidmate, dooplidmate, die totale lidmaatgetal, huisgesinne, besoekpunte, met attestate vertrek, sonder attestate vertrek, gemeenskap wat beëindig is, sterftes, attestate vertrek, sonder attestate vertrek, gemeenskap wat beëindig is, sterftes,
met attestate aangesluit, belydenis afgelê, opgeneem uit ander kerke, opgeneem na evangelisasie, gedooptes en van gedooptes na belydenisaflegging. 
rondom die Groot Opdrag (tweede punt van ooreenstemming) oor die afgelope aantal jare (2009-2015).

\section{Navorsing binne die ontluikende GKSA-leierskap}

Leierskap word vanuit 'n psigologiese perspektief beskou as 'an inevitable part of our lives' (Paschen \& Dihsmaier 2014:1). Vanuit 'n teologiese perspektief is leierskap 'n geestelike saak, aangesien Godgerigte aannames gebruik word om gelowiges te begelei om self tot Skrifgefundeerde keuses te kom (Gilbert 2004:12-38, 43). Leiers as rigtinggewers vorm die fondasie vir gesonde kerkgroei (Hendriks 2003:73-97; Schwarz 1999:187, 188). Die leraar is volgens Gilbert (2004:9) die mees erkende leier in die praksis van kerkwees (vgl. Van Helden 2010:311-322). Schwarz (1999:27, 187, 188) stel dit dat groeiende kerke leraars het wat baie hoë prioriteit gee aan effektiewe leierskap. Leraars kan derhalwe beskou word as 'n belangrike bron van inligting vir navorsing oor die stand en funksionering van leierskap in die praksis van kerkwees.

Die veranderende Suid-Afrikaanse konteks (De Klerk \& Van Helden 2011; Niemandt 2007:38-44; 2013a) eis aanpassings binne elke lewensfeer asook eerlike selfondersoek deur leraars. Dit vra 'n toenemende fokus op bereidwilligheid tot volledige gehoorsaamheid aan die Woord, om daadwerklik te herbesin (vgl. Rheeder 2012) en bekerende verandering in vernuwende denke en dade daar te stel. Verandering raak die leraar direk en daarom behoort biddend en ernstig aandag gegee te word aan álle aspekte van leierskap - ook die aspekte van 'ontluikende leierskap' wat nie tekenend is van die 'ou soort leierskap' en 'laertrek'-denke nie (Niemandt 2007:133, 134, 155, 2013b:11-191; Rheeder 2008:19; Schwarz 1999:27, 187, 188; Venter 2012c).

Nadat die kerklike statistiek in die 2009- en 2015-Almanakke nagegaan is, is 15 stellings (vgl. bespreking van die vergelyking tussen Groep A en Groep B; Addendum A) aan die betrokke leraars gestuur. Die doel was om vas te stel wat die stand van hulle denke is rondom die Groot Opdrag en die omkeerproses. Die inligting is kwantitatief benader en aan die hand van die statitiek wat deur die NWU-Statistiekdiens verkry is, word dit in ooreenstemming gebring met die vorige navorsing van 2009 (Van Helden 2010:1-289-352; Vogel 2008) en 2012 (Van Helden 2013b:1-16). Die referente is die leraars vanuit dieselfde twee provinsies (Gauteng en Limpopo se klein [K]-gemeentes) as wat in 2009 genader is om deel te wees van die steekproef oor denke rondom die Groot Opdrag (vgl. Groep A: (K)-gemeentes). Die 15 stellings van die 2014 en 2015-navorsing is gevolglik ' $n$ opvolgstudie om die stand van denke te peil - dié keer vanuit die leraar se perspektief en nié vanuit die denke van die gemeentelede soos in 2009 nie. Die stellings is saamgestel uit dokumentasie van die Deputate Omkeerstrategie (vgl. voetnoot 1 ) na afloop van die 2012-GKSA-sinodebesluit (Venter 2012a; 2012b; 2012c; 2014).

Om nie net die (K)-gemeentes in twee provinsies (Groep A) te betrek nie, is die navorsing uitgebrei om landwyd verteenwoordigend te wees. Die tweede navorsingsprojek is geloods waarby leraars betrek is wat tans (2015) in gemeentes dien met 'n lidmaatgetal wat wissel tussen 250 en 350 . Hierdie gemeentes vorm Groep B. Deur 'n kwantitatiewe benadering fokus die artikel op die denkstand van twee groepe, naamlik Groep A (opvolgnavorsing van leraars in klein (K)-gemeentes) en Groep B (eerste navorsing van leraars in gemeentes met 250 tot 350 lidmate).

Die derde navorsingsprojek betrek leraars (Groep C) in gemeentes wat volgens die 2015-Almanak 350 en meer lidmate het, en wat tydens die navorsing in 2009 en 2014 en 2015 nie vakant was of met ander gemeentes saamgesmelt het nie. In Groep C is daar 40 gemeentes waarvan 5 vakant was, 6 saamgesmelt het, 20 gekrimp het sedert 2009, en 9 gemeentes gegroei het. Die nege leraars van die gemeentes waar die lidmaatgetal hoër was as in 2009, is telefonies gekontak (Januarie tot April 2015). Gesprek is gevoer om moontlike redes vir die groei te identifiseer. Die redes vir groei word kortliks in die lig van die stellings bespreek om die denktendens te bepaal. Literatuurstudie oor missionale leierskap en denkverandering word daarna bespreek om as verwysingsraamwerk te dien waarbinne die gevolgtrekking gemaak word.

\section{Groep A: Opvolg van vorige navorsing binne klein (K)-gemeentes}

Die leraars wat in Groep A as respondente gedien het, was van gemeentes wat by navorsing volgens die 2009-statistiek betrokke was (Van Helden 2010:296). Die lidmaatgetalle van Groep A se gemeentes het op daardie stadium gewissel tussen 56 en 337 (Van Helden 2010:207). Ses jaar gelede het hierdie getalle van die betrokke gemeentes die K-gemeentes aangedui. Die lidmaatgetalle van Groep A-gemeentes word volgens die 2015-Almanak aangegee as tussen 66 en 308. Van die getalle oorvleuel met die groepering van die navorsing wat gedoen is volgens Groep B. Om konstante navorsing te bied, word egter van dieselfde 2009-K-gemeentes gebruik gemaak.

Drastiese krimping in lidmaatgetalle het die afgelope ses jaar binne die K-gemeentes plaasgevind. In 2009 was die totale aantal lidmate in die betrokke gemeentes 1811 . Die getal het intussen met 369 gekrimp tot 1442 in 2015. Een gemeente binne Groep A het sedert die vorige navorsing ontbind. Die 10 leraars binne die betrokke gemeentes het vrywillig deel van die opvolgnavorsing uitgemaak.

Die lyste wat as opvolgnavorsing aan hierdie leraars gestuur is, is op tweena aan dienavorser terugbesorg. Een leraar het nie die lys voltooi nie, maar op 10 November 2014 telefonies aan die navorser verduidelik dat hy as hulpprediker nie genoeg betrokke is om 'n regverdige mening te lug nie. Een van die gemeentes wat nie in die 2014-Almanak genoem word nie, se leraar is op 17 November 2014 telefonies gekontak om die rede daarvoor na te gaan: Die Afrikaanssprekendes van die gemeente is in die proses om met 'n naburige gemeente saam te smelt, terwyl 'n Engelstalige multikulturele gemeente in die proses is om as nuwe gemeente te ontwikkel. Aangesien 
die proses nog nie gefinaliseer is nie, is die gemeentes nie in die 2014- en 2015-Almanakke opgeneem nie.

Een respondent het op die lys ter verduideliking gestel dat hy reeds vóór die 2012-GKSA-sinodebesluit oorgegaan het tot herbesinning. Tydens hierdie proses het fasilitering wel plaasgevind, maar nié na 2012 nie ('n fasiliteerder binne die omkeerproses dui op 'n kundige persoon wat die leraars of gemeentes bystaan om die proses van herbesinning en omkeer te vergemaklik; vgl. Odendal \& Gouws 2010:231). Die laer persentasie vir die stelling oor die nut van fasilitering, moet derhalwe teen die enkele gemeente se inligting beskou word. Die vraag oor fasilitering word derhalwe nie deur die persentasie as heeltemal korrek weergegee nie.

Nege van die 11 oorspronklike (K)-gemeentes is ter sprake in die opvolgnavorsing van Groep A. Die leraars is telefonies gekontak en die navorsingsdoel is verduidelik. Elkeen het ingestem om dit per e-pos in te vul en terug te stuur. Die navorsing maak slegs gebruik van lyste wat terugontvang is, alhoewel kennis geneem word vir die rede van uitstaande lyste. Die vraelys is anoniem deur die NWU-Statistiekdiens verwerk. Die gemiddeld van elke stelling wat die leraars van die (K)-gemeentes in Groep A beantwoord het, gee ' $n$ aanduiding van die stand van denke by die leraars.

\section{Bevindings van Groep A volgens die stellings (vgl. Addendum A)}

\section{Samevatting van die bevindings - Groep A}

Die denkstand van die leraars in die (K)-gemeentes van Gauteng en Limpopo toon 'n intense strewe om volledig terug te keer na wat die Skrif beveel. Hierdie denkskuif kan só beskryf word omdat die bevindings grootliks beweging na die Groot Opdrag aantoon. Dit staan teenoor die navorsingsbevindinge van 2009 waar die Groot Opdrag opsigtelik afwesig was in die praksis van kerkwees (Van Helden 2010:331-334). Tog toon die leraar se pogings om self meer te wete te kom van die praktiese uitlewing as missionale leraar sowel as om dit daadwerklik aan die gemeente deur te gee, tekens van terughoudendheid (vgl. literatuurstudie oor leierskapsdenke in die kerkgroeibediening). 'n Uiterste vorm van terughoudendheid, naamlik om nie deel van herbesinning en bekering te wees nie, manifesteer wel binne die K-kerkpraktyke, alhoewel dit nie dominant is nie.

\section{Groep B: Die denkstand van leraars binne gemeentes met 'n lidmaatgetal van 250-350}

Die tweede groep wat deel van die navorsing was, het landwyd 33 gemeentes betrek. Hierdie gemeentes toon, volgens die 2015-GKSA-Almanak, 'n lidmaatgetal van 250 tot 350 en was deel van die GKSA voordat die wit en swart kerke saamgesmelt het. Deelname aan die navorsing was vrywillig. Alhoewel twee leraars as hulppredikers dien, was hulle bereid om die lys te voltooi, omdat hulle grootliks by die gemeente betrokke is.
Dit is noodsaaklik om te noem dat daar landwyd groot gebiede is waar gemeentes nie hierdie groot lidmaatgetalle toon nie. Volgens die 2015-Almanak is hierdie gemeentes dié in Lydenburg, Piet Retief, Groter Johannesburg, Noordwes, Burgersdorp, Karoo Kei, KwaZulu Natal en KwaZulu NatalSuid. Drie gemeentes binne hierdie gebiede toon wel die aantal lidmate, maar is vakant en word daarom nie by die navorsing ingesluit nie. Drie van die 33 leraars het verkies om die lys nie in te vul nie. Een leraar het sy keuse skriftelik aan die navorser verduidelik, terwyl die ander twee leraars nie gereageer het nie. Dertig leraars het die vraelyste voltooi.

\section{Bevindings van Groep B volgens die 15 stellings (vgl. Addendum A)}

\section{Samevatting van die bevindings - Groep B}

(Vgl. literatuurstudie oor leierskapsdenke in die kerkgroeibediening ondertoe in hierdie artikel)

Die ideaal, droom of strewe soos dit in Stelling 15 geformuleer is, leef in die leraars se denke. Daarby het leraars die pad om God se wil volledig te gehoorsaam, grootliks begin bedink. Denkaanpassings te midde van menslike tekortkominge op die onbekende pad wat ingeslaan is, bestaan inderdaad. Verder besef leraars dat hulle kennis ter wille van 'n missionale bediening behoort te bekom. As diensknegleiers word besef dat denke en dade aktief vernuwend, bemagtigend en sigbaar behoort te wees; dat dit die taak van die leraar is om inisiatief te bly neem en om biddend nuwe geleenthede binne die nuwe gemeentelike konteks na te speur. Die besef bestaan dat vernuwende dade ontplooi behoort te word; dat gewilligheid en bereidheid vereis word - gewilligheid om bemagtigend en volhardend tot hierdie stappe oor te gaan, en bereidheid om op onselfsugtige wyse vernuwende kennis te bekom, hetsy deur eie inisiatief (soos gestel deur die een respondent wat nie die lys ingevul het nie), of deur die verskillende maniere om kennis, inligting, leiding en ondersteuning te bekom. Die besef van eie tekortkominge en beklemming oor die onsekerhede rondom vernuwing kan moontlik verduidelik waarom terughouding bespeur word en gesukkel word om vinniger aan te pas. Dit verklaar moontlik die geneigdheid tot traagheid om, onder andere, nie ywerig na hulp van buite die gemeente te soek nie. Dit verduidelik ook heel moontlik die laer persentasie in denke waar sake as relatief en onbeduidend deur Groep A en B beskou word (Boks 1).

Die denkstand by Groep A en B na aanleiding van die stellings se nommers is soos volg: $\leftrightarrow$ dieselfde; $\downarrow$ een kolom laer as dieselfde nommers in Groep B; $\measuredangle \swarrow$ twee kolomme laer as dieselfde nommers in Groep B.

\section{Bespreking van die vergelyking tussen Groep A en Groep B}

Wanneer Groep A en B met mekaar vergelyk word, is daar slegs by een stelling (Stelling 15) waar $80 \%$ en hoër van albei groepe ingestem het tot die saak wat grootliks in die denke van leraars manifesteer: Ek glo dat die Here die GKSA se 
Boks 1: Skematiese samevatting van die vergelyking tussen Groep A en Groep B.

\begin{tabular}{|ll|}
\hline Groep A & Groep B \\
\hline $80 \%$ - manifesteer grootliks & 12 \\
& 5 \\
& 2 \\
$15 \leftrightarrow$ & 15 \\
$70 \%$ - 'n bestaande realiteit & \\
$2 \swarrow$ & \\
$5 \swarrow$ & \\
$12 \swarrow$ & 1 \\
$1 \leftrightarrow$ & 3 \\
& 8 \\
$8 \leftrightarrow$ & 11 \\
& 13 \\
& 4 \\
& 10 \\
$60 \%$ - saak is ter sprake & 14 \\
$3 \swarrow$ & \\
$11 \swarrow$ & \\
$4 \swarrow$ & 6 \\
& 7 \\
$50 \%$ - saak is relatief & \\
$6 \swarrow$ & \\
$7 \swarrow$ & \\
$10 \swarrow \swarrow$ & \\
$13 \swarrow \swarrow$ & \\
$40 \%$ - saak is onbeduidend & \\
$9 \swarrow$ & \\
\hline & \\
\end{tabular}

kerkgroeiproses in hierdie land wil gebruik om sy koninkryk onder al die nasies te laat kom.

Vir leraars in Groep B manifesteer die volgende drie sake egter ook reeds as $80 \%$ en hoër, naamlik dat hulle sedert 2012 grootliks bewus geword het van uitnodigings na streeksaamtrekke of inligtingsgeleenthede in verband met die kerkgroeiproses (Stelling 12). Daar word ook grootliks moeite gedoen om ouderlinge, diakens en lidmate missionaal bewus te maak en te bemagtig (Stelling 5). Verder word grootliks besef dat die leraars se persoonlike herbesinning oor die Skrif om die gemeente in die kerkgroeiproses te begelei deurslaggewend is (Stelling 2). Al drie hierdie stellings manifesteer nie grootliks in die denke van leraars in Groep A nie, alhoewel al drie as 'n bestaande realiteit beskou word $(70 \%-79 \%)$.

Vir leraars in Groep A en B is persoonlike herbesinning oor die Skrif (Stelling 1) en dat die konteks ondersoek moet word (Stelling 8) 'n bestaande realiteit $(70 \%-79 \%)$. Vir die leraars in Groep B is die volgende stellings egter ook 'n bestaande realiteit, naamlik dat prediking die gemeente in kerkgroei behoort te begelei (Stelling 3), dat gebed meer aandag behoort te kry (Stelling 11), dat gebruik gemaak behoort te word van uitnodigings na inligtingsgeleenthede (Stelling 13), en dat die kerkraad sedert 2012 meer bewus geword het van die erns of nood van die kerkgroeiproses (Stelling 4). In hierdie bestaande realiteit waar leraars se denke beweging toon, is daar ook behoefte aan 'n handleiding om die leraar of gemeente te begelei (Stelling 10). Heropleiding behoort ook plaas te vind in verband met die praktiese uitvoering van die Groot Opdrag.

Drie van hierdie stellings dra in Groep A nie dieselfde gewig as wat in Groep B as bestaande realiteit na vore kom nie. Die drie stelllings wat wel aandui dat dit ter sprake $(60 \%-69 \%)$ is in die denke van leraars in Groep A, is dat prediking die gemeente in kerkgroei behoort te lei (Stelling 3), dat gebed meer aandag behoort te kry (Stelling 11) en dat die kerkraad steeds meer bewus behoort te word van die nood en erns van die kerkgroeiproses (Stelling 4).

Twee van die stellings wat in Groep B as ter sprake $(60 \%$ - 69\%) beskou word, word in Groep A as relatiewe sake beskou $(50 \%-59 \%)$. Dit toon weereens dat Groep A in hulle denke die beweging stadiger as Groep B beleef. Die sake behels die kerkraad se besluitneming in verband met die bediening (Stelling 6), asook die gemeente se verstaan van die kerkgroeibesluit (Stelling 7). Die feit dat die persentasie verstaan en besluitneming deur die gemeente en kerkraad op die vlak van relatiewe en tersaaklike sake voorkom, benadruk die feit dat die leraars in die toekoms meer op die gemeente se denke ter wille van volledige gehoorsame verstaan en besluitneming, behoort te fokus.

Drie van die stellings wat in Groep B as bestaande realiteit $(70 \%-79 \%)$ na vore kom, word in Groep A as relatiewe sake $(50 \%-59 \%)$ gereken. Dat hierdie sake as relatief bedink word, toon dat daar in Groep A, met die kleiner gemeentes, 'n stadiger beweging in die rigting van gewilligheid ten opsigte van volledige en daadwerklike gehoorsaamheid aan die Groot Opdrag bestaan. Relatiewe gewilligheid in denke word getoon wanneer die moontlikheid daar is om van uitnodigings na inligtingsgeleenthede rakende die kerkgroeiproses gebruik te maak (Stelling 13), wanneer verkryging van kennis 'n moontlikheid word aan die hand van 'n handleiding in die kerkgroeiproses (Stelling 10), en wanneer die moontlikheid van heropleiding van leraars in verband met die praktiese uitvoering van die Groot Opdrag genoem word (Stelling 14).

Die nut van fasilitering (Stelling 9) ter wille van kennisverkryging en effektiewe denke in verband met die kerkgroeiproses, is ' $n$ saak wat die leraars in Groep B as relatief $(50 \%-59 \%)$, en die leraars in Groep A as onbeduidend $(40 \%-49 \%)$ beskou.

Om Stelling 15 (dat die kerkgroeiproses in Suid-Afrika deel uitmaak van die wil van God) nie as oordrewe nie, maar as werklik betroubaar te ag, behoort die gewilligheid om denke te verskuif náder aan die strewe van Stelling 15 sterker te vertoon. Sedert die 2012-besluit, is die minste verskuiwing na drie jaar te vind in die gewilligheid om inligting- en kennistoevoeging (deur inligtingsgeleenthede, 'n handleiding, heropleiding en fasilitering, groei in gebed) te bekom, asook om as leiers hierdie inligting en kennis gewillig in woorde oor te dra en in dade te omskep.

Hieronder is die grafiek wat die gemiddelde denkstand van Groep A en B persentasiegewys volgens die vraelys aantoon (Figuur 1).

\section{Groep C: Denkstand van leraars in gemeentes met meer as $\mathbf{3 5 0}$ lidmate}

Navorsing in 40 gemeentes met meer as 350 lidmate is kwalitatief benader. In gesprekke met die leraars van 


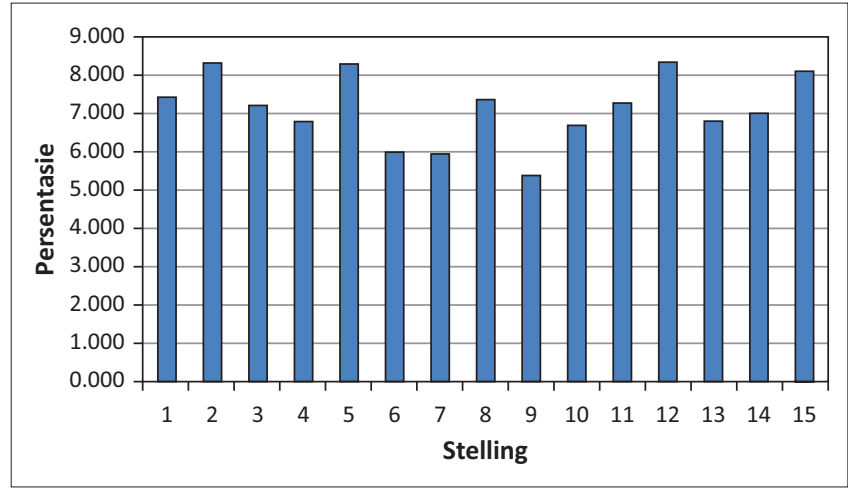

FIGUUR 1: Gemiddelde persentasie van Groep A en B volgens die vraelys.

gemeentes waar krimping tydens 2009-2015 nie voorgekom het nie, is op kerkgroei en die denke van leraars daaromtrent gefokus. Gemeentes wat volgens die 2015-Almanak in hierdie tydperk gekrimp het (20 gemeentes), waar die gemeentes vakant was of is (5) en waar samesmelting tussen gemeentes (6) plaasgevind het, het uiteraard nie gegroei nie en is nie genader om deel van die navorsing te wees nie. Die leraars van die nege gemeentes wat groei getoon het, is in Februarie tot April 2015 telefonies gekontak. Gesprek is gevoer oor die moontlike redes waarom groei plaasgevind het.

\section{Samevatting van die bevindings in Groep C}

Driekwart van die gemeentes in Groep C vertoon 'n konstante daling in lidmaatgetalle. Hierteenoor word groei by 9 van die 40 gemeentes opgemerk. Dit getuig van die strewe soos verwoord in Stelling 15 wat sigbaar word deur vernuwing. 'n Sterk bewustheid bestaan by hierdie leraars om op ingeligte en volhardende wyse missionale leierskap en bemagtiging deur prediking, toerusting en begeleiding aan die gemeentes te bied ten einde volhoubare groei moontlik te maak.

\section{Literatuurstudie oor leierskapsdenke in die kerkgroeibediening}

In die lig van die Groot Opdrag stel Rheeder (2008:41,42) dit dat leraars, as 'the principal leader' (bl. 143; vgl. Bisschoff 2008:3, 4), Jesus Christus se model vir leierskap behoort te omhels - Jesus 'who develops and empowers other leaders' (bl. 42). Vanuit 'n psigologiese perspektief word leierskap as 'one of the central social phenomena of life' (Paschen \& Dihsmaier 2014:1) beskou. 'Leadership is directed movement, it is intentional, goal-oriented, meaningful, potentially powerful, and causes others to follow', aldus Paschen and Dihsmaier (2014:6). Rheeder (2008:143) beweer verder dat die leraar die 'principal leader' is wat ' $\mathrm{n}$ span van bewese leiers behoort te bemagtig. Dié bewese leiers 'conduct ministry through teams of potential leaders', wat weer bedieningspanne bestaande uit ander moontlike leiers daarstel. Die vermeerderende bedieningskragte behoort deurentyd te fokus om te 'ontdek waar God alreeds aan die werk is en om daarby aan te sluit en so deel te neem aan God se sending' (Niemandt 2013b:51).
Hierdie verbondsmatige aktiwiteit (God en mens betrokke by God se sending) wat by missionale kerkgroei ter sprake is, vereis aanpassende denke by laertrek-gereformeerdes soos dit metofories deur die nuwe-wyn-nuwe-sakbeginsel (Matt 9:17) verduidelik word. Soms word hierdie beginsel vereng tot 'n blote aanpassing ten opsigte van 'n spesifieke kerklike aspek soos byvoorbeeld gemeentebou (Niemandt 2013b:58). Aanpassende denke en toepassing van hierdie beginsel word egter in die omvattendste sin van die woord aan gelowiges voorgehou. Ongeag hoe moeilik aanpassing is, bly dit, aldus die filosoof Johan Roussouw, 'n aksie om mense sover te kry om nuut te verstaan en die onbekende nuut te betree (Niemandt 2007:160). Guder (2015) beskryf nuwe verstaan soos volg:

The issue is not an issue of renewal, it is not an issue of better methods, it is not a question of programmes. The fundamental question is who are we in the church of Jesus Christ and what are we for, why we exist. And the response we came to was that we exist as instruments of God's Mission. (p. 4; vgl. Niemandt 2013b:142, 143).

Deur 'n opname in 2006 aangaande NG-leraars (Bisschoff 2008:4) is vasgestel dat gemeentelede roepingsbewustheid en bedieningsbevoegdheid as die belangrikste aspekte in die leierskap van 'n leraar ag. Van belang is 'the calibre of leaders' (Rheeder 2008:147; bl. 34-42). Dit is dus duidelik dat leiersvaardighede hoër geag word as die klem wat tradisioneel op akademiese toerusting tydens predikantsopleiding geplaas is (Buys 2013; Guder 2015:8; Malphurs 2004:222).

In die huidige omkeertyd waar missionale bediening groot denkaanpassings eis, kom leierskap sterk onder die vergrootglas. Aanpassings maak leraars bewus van hulle eie tekortkominge (Rheeder 2008:62, 71-76). Dit word aangevuur deur die gevoel dat 'n doodloopstraat bereik is aangaande die krisisuitdagings van krimpende en groeiende gemeentes (Wijnbeek 2007:43-45). Die besef dat harte en die hele bediening deur bekerende gehoorsaamheid volledig by die eise van God behoort aan te pas, kan grootliks bydra tot ' $n$ beklemmende gevoel by leraars; ' $n$ gevoel wat van onsekerheid en selfs angs spreek (Niemandt 2013b:43). Hierdie gevoel ontstaan omdat besef word dat leiding op nuwe, onbekende (Warren 2005:xvi) gebiede verwag word (Niemandt 2013b:11-191; Van Helden 2010:435).

Die nuwe rol van die leraar is om as dienende (vgl. Standing 2008:88, 89), transformerende en bemagtigende leier te midde van vermeerderende bemagtigdes volgens die nuwe soort leierskap te lei (Niemand 2008:167-173; Rheeder 2008:20, $67-71,142)$. Reaktiewe en terugdeinsende handelinge ter wille van selfbehoud is menslike eienskappe wat sterk na vore kom in tye van verandering (Olivier 2006:81). Psigoloë meen 'power to remove others' fears is the deciding personality trait for great leadership performance' (Paschen \& Dihsmaier 2014:38). In die lig van hierdie aanhaling kan ingesien word waarom gebrekkige leierskap telkens voorkom: Eie vrese moet eers oorkom word voordat ander se vrese hanteer kan word. Neutralisering of oorkoming van vrees behels dat verdere groei by leraars op geestelike vlak sodanig behoort 
plaas te vind dat God se liefdevolle betrokkenheid ten volle vertrou word en sodoende die vrees verdryf (Joh 4:18; Ihde 2004:440, 455). Die voorkoms van hierdie tekens kan as bevestiging dien dat denkbeweging nog nie plek gemaak het vir 'waagmoed en nuwe ontdekkings' om in die praksis van kerkwees te kan realiseer nie (Niemandt 2013b:166).

Die gebrek aan leierskap word verder op die spits gedryf waar tradisionele een-man-leierskap in die vorm van superleiersfigure manifesteer (Green 2004:340; Niemandt 2013b:134, 135; vgl. Schwarz 1999:177-181). Die superleiersfiguur (sola pastoraleiersmodel; Roxburgh 1997:64) is nêrens in die Bybel ter sprake nie. Rheeder (2008:80) beweer dat leierskap wat narsisme of aanstellerigheid toon, nie van dienende leierskap kan getuig nie. Blinde navolging van sodanige leiers vind egter grootliks nie meer aanklank by hedendaagse gelowiges nie (Niemandt 2013b:44). Aansluitend hierby is die hedendaagse verskynsel van 'n anderse manier (Brouwer et al. 2007:183; Oosthuizen 2013) van godsdienstigheid, naamlik om nie meer deel van 'n gemeente te wil wees nie en om as 'weglooplidmate' (Oosthuizen 2014) uit 'n gemeente te verdwyn. Kerkleiers wie se leiding steeds grootliks tiperend van die ou soort leierskap is, toon verder 'n onvermoë om ook hierdie tendens te keer (vgl. voetnoot 3).

Tog sê Rheeder (2008:22) dat die tendens wel gekeer, omgekeer en hervorm kan word deur 'gospel-driven and Christcentered Christian leaders' - leiers wat deur die ontluikende of nuwe soort leierskap (vgl voetnoot 3) diegene rondom hulle tot 'witnessing communities' kan begelei (Guder 2015:5, 6; vgl. Hand 17:6; Niemandt 2013b:42-69).

Van belang is Standing (2008:154-162) se mening dat 'weglooplidmate' na 'n baie lang tyd weer na die kerk toe kan terugkeer op soek na die waarheid wat kerkloosheid nie kon bied nie. Die krimpende tendens kan moontlik dan omgekeer word tot 'n groeiende tendens (vgl. golfbewegings: 'advance and recession'; Walls 2002:26). Kerkgemeenskappe behoort teen daardie tyd in denke en dade só volledig verskuif het dat persone van buite (weggeloopte lidmate sowel as ongelowiges) in 'n nuwe 'klimaat' en 'kultuur' (Niemandt 2013b:69, 133-145) 'n tuiste te kan vind (Standing 2008: 125-131).

Die diens of taak om 'n 'kultuurverandering' (Niemandt 2013b:131-145) deur te voer, vereis dat die denke van leiers ontvanklik vir verandering behoort te wees, dat denke gerig word om deelnemend te wees en om bereid te wees om vaardighede te ontwikkel (Niemandt 2013b:50, 76, 108). Die beweegrede om hierdie aanpassing te maak, is in God se liefde vir die wêreld geleë - God se liefde wat die mens deur die liefdesgebod tot gehoorsaamheid aan die missionale opdrag rig (Niemandt 2013b:38, 39, 79, 80; Van Helden 2010:403).

Rheeder (2008:55-59) formuleer die vereistes vir missionale leierskap soos volg: roepingsbesef (1 Tim 3:1), godsvrug (v. 2), 'n gedissiplineerde lewenswyse (v. 2-7) en volwasse, opofferende taakgerigtheid (v. 1). Hierdie vereistes as deel van ontluikende leierskap, is nodig vir die reeds betreede era wat konstant aanpassings eis (Niemandt 2013b:42-69) - aanpassings wat jaar na jaar intenser word (Niemandt 2007:9-15). 'Dit is 'n nuwe spel met nuwe spelreëls' (Niemandt 2013b:40) om Jesus se model van leierskap bewustelik en ten volle te volg: 'great leaders know their mission and are unalterably committed to achieving it; great leaders take care of their people; great leaders intentionally reproduce leaders' (Rheeder 2008:71).

Die gevolg is dat hierdie soort leierskap eerstens' $n$ diepgaande invloed op bykans elke moontlike terrein uitoefen; tweedens, dat dit betroubaarheid, effektiwiteit en doeltreffendheid baie hoog aanslaan; en derdens, dat onderlinge samesyn tussen individue daargestel word (Niemandt 2013b:152-156; Rheeder 2008:43, 46-52). Die nuwe eise wat aan leierskap gestel word, behels dus volgehoue toegewydheid, veral in die begeleidingsproses van gemeentelike bemagtiging (Guder 2015:6). Studies deur Schwarz (1999:27, 187, 188) het met verloop van dekades bevestig dat groeiende kerke oor leraars beskik wat effektief aandag gee aan hulle bestuurstake en leierskapsverantwoordelikhede. Die praksis van kerkwees behoort dus só deur leiers voorberei te word dat die Gees op organiese manier groei sou kon bewerkstellig (Niemandt 2013b:33, 2007:157, 159).

Die grootste belemmering in leierskap bly egter die mens en sy gevestigde denkwyses (Guder 2015:6; vgl. Olivier 2006:141). In die proses van herbesinning - in die wydste sin van die woord - wys Rheeder (2008:58) daarop dat leierskap 'n aanbiddingshandeling is (vgl. 2 Tim 4:5). 'n Aanbiddingsgesindheid as deel van leierskapsdenke spruit uit die mate van vervulling deur die Heilige Gees (Botha 2006:23). Die Gees en Woord (waarheid) bewerk verandering in denke, maar terselfdertyd eis verandering dat die mens die verantwoordelikheid aanvaar om die waarhede te ken en daadwerklik toe te pas (Rheeder 2008:17, 54). Traagheid in soeke om deur die Woord en Gees vervul en verander te word, kan in 'wankelmoedige leierskap' realiseer (Warren 2005:xvi; vgl. Rheeder 2008:71). Dit lei telkens tot leemtes in die bediening, stagnasie by die leraar sowel as by die gemeente (Botha 2006:23; Warren 2005:21).

Stagnasie word gereeld met menslike selfgerigtheid en onaanpasbaarheid verbind - elemente wat die werking van die Gees bemoeilik (Niemandt 2007:160, 161). Terselfdertyd kan missionale traagheid en min gebede herlei word na onvoldoende toerusting van bestaande leraars, leiers en ouderlinge (Botha 2006:22, 23; Van Rooy 2007:31,32). Rheeder (2008:59) verwoord traagheid as luiheid (vgl. Spreuke) 'n eienskap wat nie sprekend is van 'n Geesvervulde gelowige nie. Onwilligheid om Geesgerigte denkaanpassings daadwerklik te gehoorsaam, dra verder by tot die verskynsel dat moeite ervaar word om by die eise van die nuwe soort leierskap en oorgangstyd aan te pas (Du Toit et al. 2002:243; Niemandt 2007:37, 2013b:43).

Swakhede of tekortkominge kan egter omgekeer word tot ' $\mathrm{n}$ krag. As bereidheid tot gehoorsame selfondersoekende 
bekering en vernuwing bestaan, kan dit die Gees se wil wees om bemagtigend te werk te gaan - bemagtigend deurdat selfkennis (van eie swakhede) die gelowige dring tot refleksie (Ps 62:1) (Rheeder 2008:108), afhanklikheid van en oorgawe aan die Gees (vgl. 2 Kor 12:10). Die lewens van God se kinders kan dan daadwerklik deur die leiers aangeraak en verander word - verandering wat realiseer deur vaardigheid in 'modelling, mentoring, motivating, managing and ministering' (Rheeder 2008:87).

Lukas 2:52 bied die bybelse riglyn waarvolgens leiers deur die Heilige Gees ontwikkel of verander word (Rheeder 2008:103-114). Eerstens word intellektuele vorming getoon deur wysheid wat sigbaar word in keuses waardeur God geëer word (Spr 9:10). Die leiers se statuur, gevorm deur dissipline wat onder andere selfbeheersing (Gal 5:22) en om 'n lewende offer te wees (Rom 12:1; 1 Kor 9:27; 10:31) insluit, dui op fisiese vorming wat die leier voorberei vir verdere spirituele vorming, en omgekeer. Gesonde spirituele vorming vind plaas as gevolg van Christusgesentreerde dissipelskap (guns by God) en deur verhoudings (guns by die mens) gedryf deur liefde teenoor Jesus Christus. 'n Christenleier, wat die leiersroeping biddend aanpak en beklee is met die wapenrusting van God (Ef 6:13-16), behoort soos Jesus op te tree as 'The Good Shepherd, the Suffering Servant, and Vigilant Superintendent' (Ps 23; Joh 13:4-5; 1 Tim 3:4-5; Rheeder 2008:22, 105-126).

Om by die oorlogstryd-en-oorwinningsmetafoor (2 Tim 4:7; 2 Kor 10:4; Jos 5:14) aan te sluit, is dit nodig om bewus te wees van tipes leierskappe (Rheeder 2008:129-137). Visionêre, strategiese en taktiese leierskap is al drie noodsaaklik, alhoewel eersgenoemde gewoonlik die eerste rigtinggewende stappe bied. Visie is die prentjie waarnatoe beweeg wil word. Dit verwoord die verlangde veranderde praktyk (Puccio, Mance \& Murdock 2011:138), maar 'Whether you are a visionary, strategic or tactic leader - or a hybrid - be a selfless leader who inspires ... It's the biblical model of leadership' (Rheeder 2008:138).

Aspekte wat dus belangrik is om die praksis van kerkwees in 'n 'leadership factory' (Rheeder 2008:148) te omvorm en volgens Handelinge 17:6 die hele wêreld in beroering te bring (vgl. Rheeder 2008:22), is die volgende: onversadigbare leerders wat elke geleentheid aangryp, ander lei om te leer en geoefen is om leermomente te benut. In die proses van denkverskuiwing deur leer en die oordrag daarvan, behoort van duidelike en maklik onthoubare spreekwoorde volgens Jesus se voorbeeld, of akronieme gebruik gemaak te word. Sodoende word die denke verskuif om op die lang duur blywend van waarde te wees (Rheeder 2008:101, 147-157).

\section{Denkverskuiwingsproses}

Skriftuurlike denkverandering aan die hand van Romeine 12:2 beteken dat die imperatief die gelowige tot gewillige denkverandering oproep wat deur vernuwende dade bevestig word (vgl. Rheeder 2008:21; Van Helden 2013b:
1-16). Gewillige denkvernuwing en dade wat daarby pas, bly in die lig van Filippense 2:12 en $13^{6}$ die werk van die Gees wat verandering moontlik maak (Niemandt 2013b:178; Rheeder 2008:30; Strong 2007:107-110).

In die denkverskuiwingsproses is daar stappe wat deur kommunikatiewe handeling beweeg word om te realiseer as ' $n$ volgende insig. Dit gaan met toevoeging van inligting of kennis gepaard (Heitink 1999:319; Rheeder 2008:148-156). In die luisterproses (Niemandt 2013b:119-121) word van 'n egosentriese denkpatroon wegbeweeg na 'n punt waar sensitiwiteit vir ander persone se insigte of kennis ervaar word. Daarna word deur die aanvanklike voorveronderstellings of kennis gebreek en word die saak deur die oë van die ander persoon waargeneem. Dit is die punt waar denke openheid ten opsigte van die nuwe werklikhede bereik.

As denke nie verander nie, sal verandering in dade moeilik plaasvind (Strong 2007:106-108, 128). Deur erkenning van die toestand waarin verkeer word, (bv. krimpende lidmaatgetalle), kom gelowiges tot selfondersoek daaromtrent. Dit lei tot die besef dat die toestand behoort te verander. Die beweging in denke gaan oor tot die neem van nuwe besluite, omdat daar tot nuwe verstaan en nuwe bereidheid gedring is (Rheeder 2012). Hierna volg die hantering van die nuwe keuses. Veranderinge kan grootliks deur kreatiwiteit, verbeelding en die gebruik van metafore aangevuur word (Niemandt 2013b:92-108, 134, 135; Puccio et al. 2011:20-22).

Waarderende Ondersoek as kommunikatiewe aksie bied 'n praktiese aanpak om denkverandering te laat realiseer (Chaffee 2005:1-30; Niemandt 2007:69, 70; Van Helden 2014a:1-11). Aan die hand van die stoomrollertendens ${ }^{7}$ kan die stand van verandering waargeneem word deur die beweging in die emosionele en rasionele vlakke tydens die proses te volg (Brouwer et al. 2007:49; vgl. Van Helden 2010:11; 2013b).

\section{Gevolgtrekking}

Hierdie artikel is 'n samevatting van 'n derde studie om inligting deur te gee oor hoe denke binne die GKSA besig is om van 'laertrek'-denke tot missionale denke te verskuif. Verskuiwing ter wille van 'n geleidelike verbeterende praktyk is die terrein van Praktiese Teologie. Die beginpunt van navorsing oor verskuiwende denke binne die GKSA het in 2009 begin toe nagegaan is in hoe 'n mate die Groot Opdrag deur die tradisionele 'laertrek'-denke gehoorsaam word. Aangesien missionale gehoorsaamheid nie werklik bewustelik voor 2012 bedink is nie, is tydens die 2012-GKSASinode besluit om voortaan werklik bewustelik en

6.Werk julle eie heil uit met vrees en bewing (Ou Vertaling), want dit is God wat julle gewillig en bekwaam maak om sy wil uit te voer (Nuwe Vertaling).

7.Aanvanklik word emosies soos opwinding, skok, verwarring, veglustigheid of ontwyking van nostalgie, woede, angs, skuld en 'n gevoel van verlies ervaar. Dan volg die emosionele keerpunt wanneer begeer word om deel te wees van die verandering of om glad nie deel daarvan te wees nie. By eersgenoemde tree verandering indeur ontdekking van nuwe is is belangrik. Toetsing van gebeure vind plaas en dit lei tot ' $n$ herverbintenis to die denkverskuiwing wat opnuut opwinding bring. Hierdie stappe begin by ' $n$ emosionele ervaring en eindig by ' $n$ rasionele ervaring. 
daadwerklik te bekeer om vollediger gehoorsaam te wees aan die Groot Opdrag.

Binne die Praktiese Teologie is só 'n verskuiwing in die praksis van kerkwees van groot belang en behoort die verbeterende tendense aangetoon te word. Hierdie artikel het aangetoon dat die denke van GKSA-leraars as gemeentelike leiers tans grootliks op die GrootOpdrag en die implikasies daarvan fokus. Dit is 'n denkbeweging wat algaande sterker ontluik sedert die eerste navorsing in 2009 plaasgevind het. Omdat hierdie 'n derde studie is met GKSA-gelowiges en die Groot Opdrag (kerkgroei) as ankerpunte, is dit 'n empiriese toevoeging tot 'n diachroniese beskrywing van denkverskuiwing.

Die breë tendens van bereidwilligheid om die pad van bekerende denkverskuiwing in die GKSA aan te pak, word by al drie groepe leraars (Groep A, B en C) bespeur. 'n Ernstige strewe bestaan om die wil van God vollediger as voor 2012 te gehoorsaam. Die besef bestaan dus dat 'n missionale bedieningspraktyk daargestel behoort te word. Verskuiwing vanaf uitermate min missionale denke voor 2012 na 2015 wat toon dat daar 'n intense besef hieromtrent is, wys dat denke inderdaad verskuiwing ondergaan het. Die breë tendens is dat 'n ontluikende gewilligheid bestaan om by die eise van die Groot Opdrag aan te pas.

In die vinnig veranderende Suid-Afrikaanse konteks, die komplekse oorsake van kerkkrimping en die lidmaatgetalle wat steeds bly afneem, is dit egter duidelik dat die ontluikende denke uiters sporadies oorgaan tot dade. Die neem van vernuwende wilsbesluite kan binne die ses jaar van navorsing (2009-2015) nie as 'n verskuiwende tendens waargeneem word nie.

Moontlike redes vir die stadige verskuiwing kan wees dat leraars beklem of vreesagtig voel oor hulle toerusting rakende missionale bedieningsbevoegdheid. Redes soos selfgerigtheid en traagheid om tot besluitneming oor te gaan, kan moontlik tekens wees van die houvas van 'n steeds gestagneerde praksis (Praksis 1). Sodanige redes belemmer vernuwende denke ter bereiking van 'n verbeterende praksis (Praksis 2).

Sedert 2012 het die bereidheid tot toevoeging van kennis (selfkennis, missionale kennis) en vaardighede by die leraar en dié wat bemagtig word, toegeneem. Die tempo van kennistoevoeging en die oorgaan tot vernuwende wilsbesluite vind egter steeds nie neerslag in vernuwende dade nie. Dit verduidelik moontlik waarom vernuwing rondom gebede, toevoeging van kennis in die wydste sin van die woord en bemagtiging van die gemeentelede nog nie as nuwe identiteit en nuwe kultuur binne gemeentes voorkom nie. Kennisname van die nuwe spelreëls van leierskap word nog nie deur vernuwende dade getoon nie. Ontluikende denke word op hierdie wyse bemoeilik.

Die bereidwillige, maar wankelmoedige bene aan die voorpunt van die ongekaarte missionale toekomspad, getuig in 2015 van die sterk soeke na vernuwende persoonlike aanbiddingsdenke by leraars. Hierdie soeke spreek van leraars se strewe om as Geesvervulde en gehoorsame leiers in die proses van denkverskuiwing wel tot missionale dade oor te gaan. Geloofsmoed om die gemeente se denke deur, onder andere, prediking tot aanpassing te rig, behoort uit die persoonlike herbesinning geput te word wat tans baie hoë prioriteit geniet. Onder die leiding van die Gees kan vertrou word dat denke in die volgende aantal jare sal verskuif tot moedige geloofsdade, selfs geloofspronge - geloofspronge weg van gestagneerde leierskap af en algaande meer in die rigting om as instrument van God, in sý missie, hier en nou te leef (Niemandt 2013b:157-166).

\section{Erkenning Mededingende belange}

Die outeur verklaar dat sy geen finansiële of persoonlike verbintenis het met enige party wat haar nadelig kon beïnvloed in die skryf van hierdie artikel nie.

\section{Literatuurverwysings}

Bisschoff, J., 2008, 'Leraar se waarmerk as leier', Kruisgewys, 4, April, bl. 4.

Botha, N., 2006, 'Nou ken ons ons ellende beter', Kerkblad, Mei, bl. 47.

Brouwer, R., De Groot, K., De Roest, H., Sengers, E. \& Stoppels, S. (reds.), 2007, Levend liggaam: Dynamiek van christelijke geloofsgemeenschappen in Nederland, Kok, Kampen.

Buys, F., 2013, e-pos, 21 April, buys.flip@gmail.com.

Chaffee, P.C., 2005, Claiming the light: Appreciative inquiry and congregational transformation, viewed 4 August 2013, from www.congregationalresources.org.

De Klerk, B.J. \& Van Helden, P., 2011, ‘Oorsake van kerkkrimping binne die tradisioneel Afrikaanssprekende gereformeerde kerke in Suid-Afrika', Verbum et Ecclesia 32(1), Art. \#477, 10 pages. http://dx.doi.org/10.4102/ve.v32i1.477

Dreyer, W., 2009, Tendense in die kleiner kerk en gemeente, besigtig 12 Januarie, vanuit http://www.google.co.za/url?sa=t\&rct=j\&q=\&esrc=s\&source=web\&cd= $16 \&$ ved $=0$ CDgQFjAFOAo\&url=http $\% 3 \mathrm{~A} \% 2 \mathrm{~F} \% 2 \mathrm{Fwww}$.gemeentes.co.za $\% 2 \mathrm{Fdok}$ umente $\% 2$ Fkruisgewys $\% 2$ Fklein gemeentes $\% 2$ FNHKA $\% 2520$ Klein $\% 2520$ Kerk.

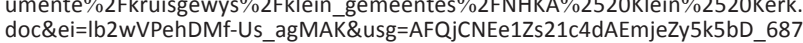
doc\&ei=lb2wVPehDMf-Us_agMAK\&usg
CQ\&sig2=mQ366Dsu1puoeigM8IKWvQ

Du Toit, F., Hofmeyr, H., Strauss, P. \& Van der Merwe, J, 2002, Moeisame pad na vernuwing: Die NG Kerk se pad van isolasie en die soeke na 'n nuwe relevansie, Barnabas, Bloemfontein.

Gilbert, D.E., 2004, “"Deep change” or "slow death"? A practical road guide for the highway of change: A learning manual for church boards', PhD thesis, Faculty of Theology, Western Theological Seminary, MI.

Gill, R., 2003, The 'Empty' Church Revisited, Ashgate, Burlington.

Green, M., 2004, I believe in the Holy Spirit, William B. Eerdmans, Grand Rapids, MI.

Guder, D., 2015, 'Turn around and church growth', paper presented at the Gereformeerde Kerk Randburg, 4th May.

Hadaway, C.K \& Marler, P.L., 2005, 'How many Americans attend worship each week? An alternative approach to measurement', Journal for the Scientific Study of Religion 44(3), 307-322. http://dx.doi.org/10.1111/j.1468-5906.2005. 00288.x

Heitink, G., 1999, Practical theology history theory action domains: Manual for practical theology, transl. R. Bruinsma, William B. Eerdmans, Grand Rapids, MI.

Heitink, G., Pieterse, H.J.C. \& Vos, C.J.A., 2000, "n Poging tot saamdink', Praktiese Teologie in South Africa 15(2), 53-71.

Hendriks, H.J., 1999, 'Verwagting vir die nuwe millennium: Gaan Gereformeerde Kerke groei, kwyn of verdwyn?', Woord en Daad 13(Lente), 17-19.

Hendriks, H.J., 2000, 'Die Suid-Afrikaanse Godsdienstige landkaart aan die begin van die nuwe millennium: tendense in die eerste post-apartheid bevolkingsensus', Praktiese Teologie in Suid-Afrika, 15(2), 73-97.

Hendriks, H.J., 2003, Die toekoms van die kerk, die kerk van die toekoms, besigtig $10 \mathrm{Mei}$ 2010, vanuit http://academic.sun.ac.za/theology/Profiles/Profile_documents/ Prof_Jurgens_Hendriks_Intreerede.pdf.

lannaccone, L. \& Everton, S., 2004, 'Never on sunny days: lessons from weekly attendance counts', Journal for the Scientific studies of religion, 43(2), 191-207. $\mathrm{http}: / / \mathrm{dx}$.doi.org/10.1111/j.1468-5906.2004.00227.x

Ihde, D. (ed.), 2004, Paul Ricoeur the conflict of interpretations essays in hermeneutics, Continuum, London. 
Kleynhans, S., 2013, Insiggewende artikel van ons moderator oor krimpende gemeentes!, besigtig 10 Januarie 2015, vanuit http://ngverwoerdpark.org.za/ gemeentes!, besigtig
profile/SteynKleynhans

Malphurs, A., 2004, Planting growing churches for the 21st century, Baker Books, Grand Rapids, MI.

Niemandt, N., 2007, Nuwe drome vir nuwe werklikhede, Lux Verbi.BM, Wellington.

Niemandt, N., 2013a, Krimpende lidmaatgetalle, besigtig 8 Januarie 2015, vanuit https://www.facebook.com/nelus.niemandt/posts/10151206315221975

Niemandt, N., 2013b, Nuwe leiers vir nuwe werklikhede, Christelike Uitgewersmaatskappy, Vereeniging.

Odendal, F.F. \& Gouws, R.H., 2010, Handwoordeboek van die Afrikaanse taal, 5e uitgawe, L. Botha \& I. Wasserfall, Pinelands.

Olivier, I.J., 2006, 'The strategic task of the church in creating spaces for spirituality' PhD thesis, Faculty of Theology, North-West University, Potchefstroom Campus, Potchefstroom.

Oosthuizen, J., 2013, Krimpende kerke nie net sleg, besigtig 8 Januarie 2015, vanuit http://www.glodiebybel.co.za/component/content/article/717-krimpende-kerknie-net-sleg.html

Oosthuizen, J., 2014, Krisis kom vir leë kerke, besigtig 8 Januarie 2015, vanuit http:// www.ngvishoek.co.za/index.php?option=com content\&view=article\&id $=1255 \%$ 3Akrisis-kom-vir-lee-kerke\&ltemid=105

Pansegrouw, D., 2015, e-pos, 30 Maart, dirkmarja@mweb.co.za.

Paschen, M. \& Dihsmaier, E., 2014, The psychology of human leadership: How to develop charisma and authority, Springer, Heidelberg.

Puccio, G.J., Mance, M. \& Murdock, M.C., 2011, Creative leadership skills that drive change, 2nd edn., Sage Publications, Thousand Oaks, CA.

Rheeder, H., 2008, The leadership dynamic, Crossway Books, Wheaton, IL.

Rheeder, H.L., 2012, 'From embers to a flame: How God can revitalize your church', paper delivered at From Embers to a Flame Conference, Good News Convention Centre, Muldersdrif, 8-10 May.

Rheeder, H. 2013, Interview with Harry Rheeder, Part 1, viewed 21 April 2013, from https://www.youtube.com/watch?v=LIZ3qNwUjQM\&list=UUquovPPE8bMQsdI6 RZXiDYg

Roxburgh, A.J., 1997, The missionary congregation, leadership and liminality, Trinity Press International, Harrisburg, PA.

Schwarz, C.A., 1999, Paradigm chift in the church - How natural church developmen can transform theological thinking, ChurchSmart Resources, Emmelsbüll.

Schwarz, C.A., 2000, Natural church development: A guide to eight essential qualities of healthy churches, S.A. Church Wise, Randhart.

Smietana, B., 2006, 'Statistical illusion: New study confirms that we go to church much less than we say', Christianity Today 50(4), 85-88.
Standing, R., 2008, Re-emerging church strategies for reaching a returning generation, The Bible Reading Fellowship, Abingdon.

Strong, P., 2007, 'Romans 12:2 as an important paradigm for transformation in a Christian: A practical theological study', PhD thesis, Faculty of Theology, NorthWest University, Potchefstroom Campus, Potchefstroom.

Van Helden, S., 2010, "n Hermeneuties-empiriese strategie rakende die verskynsel van kerkkrimping in tradisioneel Afrikaanse "susterkerke" in Suid-Afrika - 'n Praktiesteologiese studie', PhD-proefskrif, Fakulteit Teologie, Noordwes Universiteit, Potchefstroom.

Van Helden, P., 2013a, 'Denke as krisisterrein in die verskynsel van kerkkrimping by tradisioneel Afrikaanssprekende susterkerke', Verbum et Ecclesia 34(1), Art. \#677, 12 pages. http://dx.doi.org/10.4102/ve.v34i1.677

Van Helden, S., 2013b, 'Verskuiwende denke van die 2012-GKSA-Sinode', In die Skriflig/In Luce Verbi 47(1), Art. \#117, 16 pages. http://dx.doi.org/10.4102/ids. v47i1.117

Van Helden, S., 2014a, 'Die Waarderende Ondersoek aanpak as nuttige instrument vir verandering', In die Skriflig 48(1), 11. http://dx.doi.org/10.4102/ids.v48i1.1831

Van Helden, S., 2014b, 'Aspekte van 'n omkeerproses', In die Skriflig 48(1), Art. \#1696, 13 pages. http://dx.doi.org/10.4102/ids.v48i1.1696

Van Rooy, K., 2007, 'Sendingwerk in die toekoms ... Hoe en waarheen?', Die Kerkblad, April, bl. 30-32.

Venter, P., 2012a, Verslag van werkgroep 2: Kultuur, e-pos, 28 Mei, dspietventer@ oosdoppers.co.za.

Venter, P., 2012b, Sydneyverslag, e-pos, 29 Mei, dspietventer@oosdoppers.co.za.

Venter, P., 2012c, Deputate Omkeerstrategie eksegetiese lyne: Verslag werkgroep 1, e-pos, 30 Mei, dspietventer@oosdoppers.co.za.

Venter, P., 2014, Lys van gemeentes en meerdere vergaderings wat deur deputate besoek is om inligtingsvergaderings/toerustingsgeleenthede oor die Omkeerstrategie te hou, e-pos, 31 Okt, dspietventer@oosdoppers.co.za.

Vogel, W., 2008, Almanak van die Gereformeerde Kerke in Suid-Afrika, Jrg. 134, V\&R Drukkery (Edms.) Bpk., Pretoria.

Vogel, W., 2014, Die Almanak van die Gereformeerde Kerke in Suid-Afrika vir die jaar 2015, Jrg. 141, V\&R-Drukkery (Edms.) Bpk., Pretoria.

Walls, A.F., 2002, The cross-cultural process in Christian history - Studies in the transmission and appropriation of faith, T\&T Clark, Edinburgh.

Ward, K., 2004, 'Is New Zealand's future churchless?' Stimulus, 12(2).

Warren, R., 2005, Doelgerigte kerk, Struik Christelike Boeke, Kaapstad.

Wijnbeek, M., 2007, 'Die kerke loop leeg ... en leër ... en leër', Die Kerkblad, Julie, bl. 43-45.

Wilhelm, M.O., Rooney, P.M. \& Tempel, E.R., 2007, 'Changes in religious giving reflect changes in involvement: age and cohort effects in religious giving, secular giving and attendance', Journal for the Scientific Study of Religion, 46(2), 217-232. $\mathrm{http}: / / \mathrm{dx}$.doi.org/10.1111/j.1468-5906.2007.00352.x 


\section{Addendum 1: Bevindings: Groep A-C}

Interpretasieriglyne

\author{
Skaal 1-4: onbeduidend \\ 5: relatief \\ 6: ter sprake \\ 7: 'n bestaande realiteit \\ 8: manifesteer grootliks \\ 9: manifesteer uitermate baie \\ 10: manifesteer as uitgangspunt
}

Die bevindings word beskryf vanaf die hoogste persentasie (8.0) tot die laagste (4.2). Daardeur word persentasiegewys getoon hoe gedink word oor die proses. Stelling 15 vertoon die hoogste en 9 vertoon die laagste.

\section{Groep A: denke van leraars in K-gemeentes}

Een stelling: $80 \%$

Stelling $15(8,0)$ : Sewe van die nege respondente het aangetoon dat hulle glo die Here wil die GKSA se kerkgroeiproses in hierdie land gebruik om sy koninkryk onder al die nasies te laat kom.

Vyf stellings: $70 \%-79 \%$

Stelling 2 (7.88), 5 (7.66), 1 (7.33), 8 (7.33) en 12 (7.33) sentreer rondom:

- persoonlike herbesinning;

- moeite wat gedoen word om ouderlinge/diakens/lidmate missionaal bewus te maak en te bemagtig;

- die omkeerbesluit as deel van persoonlike herbesinning terug na die Skrif toe;

- die belang van die konteks van die gemeenskap;

- bewuswording van inligtingsgeleenthede in verband met die kerkgroeiproses.

Drie stellings: $60 \%-69 \%$

Stelling 3 (6.66), 11 (6.62) en 4 (6.11) sentreer rondom:

- die prediking om die kerkraad en lidmate missionaal bewus te maak;

- gebed in die gemeente;

- die kerkraad bewus te maak van die nood en erns van die kerkgroeiproses.

Vyf stellings: $50 \%-59 \%$

Stellings 6 (5.88), 7 en 14 (5.66), 10 (5.55) en 13 (5.44) sentreer rondom:

- die kerkgroeibesluit en kerkrade se besluitneming daaromtrent;

- die verstaan van die kerkgroeibesluit deur lidmate;

- die nut van 'n handleiding vir die kerkgroeiproses;

- die heropleiding vir leraars;

- die gebruikmaak van uitnodigings na inligtingsgeleenthede wat fokus op die kerkgroeiproses.

Een stelling: $40 \%-49 \%$
Stelling 9 (4.22) fokus op die nut van fasilitering in die gemeentes sodat die kerkgroeiproses beter kan kommunikeer.

Groep B: denke van leraars in gemeentes met 250-350 lidmate

Die hoogste persentasies is $80 \%$ en hoër en die laagste is $50 \%-$ $59 \%$.

\section{Vier stellings: $80 \%$ en hoër}

Stellings 12 (8.63), 5 (8.46), 2 (8.43) en 15 (8.13) se gemiddeld is 8 en hoër. Hierdie stellings sentreer op:

- bewuswording van uitnodigings na streeksaamtrekke en inligtingsgeleenthede in verband met die kerkgroeiproses;

- moeite wat gedoen word om ouderlinge/diakens/lidmate missionaal bewus te maak en te bemagtig;

- die leraar se persoonlike herbesinning terug na die Skrif toe as deurslaggewend beskou om die gemeente te begelei;

- dat geglo word dat die Here die GKSA se kerkgroeiproses in hierdie land wil gebruik om sy koninkryk onder al die nasies te laat kom.

\section{Agt stellings: $70 \%-79 \%$}

Agt (8) stellings se gemiddeld val binne 7.0 tot en met 7.5 naamlik stelling 1 (7.46), 3 (7.36), 8 (7.36), 11 (7.43), 13 (7.23), 4 (7.00), 10 (7.03) en 14 (7.40). Dit sentreer op die besluit wat tydens die 2012-Sinode geneem is wat deel uitmaak:

- van die respondent se persoonlike herbesinning terug na die Skrif toe;

- dat die besluit deel is van die respondent se prediking om die gemeente te lei;

- dat die konteks van die gemeenskap waarbinne die gemeente geplaas is, ondersoek moet word sodat die gemeente daarvolgens missionaal gerig kan word;

- dat die rol van gebed in die proses nuttig sal wees vir die leraar, sowel as vir die gemeente;

- dat gebruikgemaak is van die uitnodigings na streeksaamtrekke en inligtingsgeleenthede in verband met die proses;

- dat die kerkraad sedert 2012 bewus geword het van die erns en nood van die kerkgroei-/omkeerproses;

- dat riglyne aan die hand van 'n handleiding nuttig sal wees vir die leraar en die gemeente;

- dat heropleiding van leraars in verband met die praktiese uitvoering van die Groot Opdrag behoort gekry te word.

Die feit dat 8 van die 15 stellings se gemiddeld binne 70\% $79 \%$ val, wys dat meer as die helfte van hierdie stellings beskou word as bestaande realiteit.

Twee stellings: $60 \%-69 \%$

Slegs twee (2) stellings naamlik Stelling 6 en 7 se persentasies vertoon 6.03. Dit fokus op die kerkgroeibesluit:

- wat dien as riglyn vir die kerkraad se besluitneming in verband met die bediening, asook die 
- verstaan van die kerkgroeibesluit deur die lidmate in die gemeente.

\section{Een stelling: $\mathbf{5 0} \% \mathbf{- 5 9} \%$}

Die laaste stelling naamlik $9(5,73)$ fokus op die nut van fasilitering. Die respondente (17) het aangetoon dat fasilitering wel nuttig sal wees, aangesien dit beskou word as ter sprake wees (5), as bestaande realiteit nuttig sal wees (1), as grootliks (5), uitermate baie (4) en as nuttige uitgangspunt (2). Van die 30 respondente het 13 aangedui dat fasilitering as relatiewe (3) en as onbeduidende saak (10) beskou word.

\section{Groep C: Redes vir groei}

Die volgende is deur leraars genoem as die hoofredes waarom groei in die gemeentes van Groep C plaasgevind het. Na afloop van die gesprekke is die redes in orde van belangrikheid na aanleiding van die frekwensie van die gegewe redes, soos volg vasgestel:

1. Aktuele prediking en die Woord wat sentraal staan.

2. Liturgie in die eredienste is vryer en meer dinamies.

3. Die onderlinge samesyn, belewenis en uitreik tussen gelowiges is liefdevol, vriendelik, gasvry, oop en spontaan. Die warmte of ontvanklikheid van die gemeente, saam met vriendskapsevangelisasie en evangelisasie, bied 'n tuiste vir kerklos mense, asook vir lidmate uit ander kerkverbande. Die kerk is sigbaar.

4. Demografiese verskuiwing weens werksgeleenthede in stede/ kusdorpe (verstedeliking).

5. Kerkplanting.

6. Ouderlingtoerusting.

Word die gemiddeldes van Groep A en B as denkriglyne vir verskuiwende denke geneem, kan bogenoemde redes vir groei in die 9 gemeentes, in die lig van die denkriglyne, soos volg geïnterpreteer word:

Nege van die 40 gemeentes dui op een na, op ' $n$ kwart van die moontlike navorsingsgemeentes. In die lig van die krisis waarin die gereformeerde kerke verkeer (Van Helden 2013a), is elke denkverandering of denkverskuiwing wat sigbaar word in groeiende getalle, 'n saak waarvoor God gedank en geloof moet word. Groei kan beskou word as 'n teken van geloofswaagmoed, geloofsvertroue, doelbewuste beplanning en die volhardende deurvoer van die bewuste besluit om meer volledig gehoorsaam te wees aan die Groot Opdrag. Een uit vier denke in verband met die kerkgroeiproses vertoon tekens van 'n moontlike ontkiemfase; 'n fase wat spreek van leraars wat in die rigting beweeg van bewustelike missionale leierskap binne die betrokke gemeentes.

Soos by die leraars in Groep A en B kan Stelling $\mathbf{1 5}$ ook grootliks ( $80 \%$ en hoër) beskou word as die rede vir die denkbeweging by Groep C-leraars - vergelyk die redes by punt 3 (evangelisasie) en 5 (kerkplanting). Die feit dat die redes derde en vyfde plekke inneem, bevestig dat ontwikkeling grootliks uitgebrei kan word rakende missionale bevoegdheid en vaardighede.

Stelling $\mathbf{2}$ en $\mathbf{5}$ realiseer ook in die redes wat gegee is. Stelling 2 kom na vore deur die leraar se begeleiding soos gestel word in die redes gegee by punt $1-3,5,6$, terwyl die leiding van die leraar direk na vore kom deur bemagtiging en begeleiding soos punt 6 dit stel in verband met Stelling 5. Die feit dat al die redes, behalwe punt 4 , by Stelling 2 genoem word, bevestig dat leraars in hulle denke gerig word én gerig is op Skrifgetroue begeleiding. Dat Stelling 5 die sesde plek inneem, toon dat leraars in die beginfase is om toenemend meer moeite te doen om missionale bewussyn en begeleiding te bewerkstellig.

As na die verskil tussen Groep A en B gekyk word, kan na aanleiding van die rede gegee by punt 1 , met sekerheid gestel word dat Stelling 3 nie net as bestaande realiteit (70\% - 79\%) by die 9 leraars in Groep C realiseer nie, maar dat dit grootliks ( $80 \%$ en meer) realiseer. Dieselfde kan gestel word rondom stelling 8 , naamlik dat die gemeentelike konteks met die missionale doel van die gemeente voor oë, sterker na vore kom deur die redes gegee by punt 2, 3 en 5 .

$\mathrm{Na}$ aanleiding van die gemiddeldes van Groep A en B kan Stelling 4 persentasiegewys hoër geag word as $60 \%$ (ter sprake), aangesien die redes vir groei aangegee word as punt 2, 3, 5, 6. In dieselfde asem kan gestel word dat Stelling 6 en 7 persentasiegewys hoër geag kan word as die redes vir groei volgens punt 1-3, 5 en 6 hiermee in verband gebring word.

Die ander 7 stellings kan nie direk verbind word met die redes vir groei wat gegee is nie. Aangesien die redes vir groei spreek van 'n ontluikende en/of vernuwende beweging, kan gewaag word om te sê dat hierdie ander 7 stellings moontlik ook met dieselfde missionale denkingesteldheid benader word. 